\begin{tabular}{|c|l|}
\hline Title & $\begin{array}{l}\text { Effects of Drainage on Open-Water Mire Pools: Open W ater Shrinkage and V egetation Change of Pool Plant } \\
\text { Communities }\end{array}$ \\
\hline Author(s) & Lee, A hy oung; Fujita, Hiroko; Kobay ashi, Haruki \\
\hline Citation & $\begin{array}{l}\text { Wetlands, 37(4), 741-751 } \\
\text { https:/doi.org/10.1007/313157-017-0907-3 }\end{array}$ \\
\hline Issue Date & 2017-08 \\
\hline Doc URL & http://hdl.handle.net/2115/71425 \\
\hline Rights & The final publication is available at link.springer.com via http://dx.doi.org/10.1007/s13157-017-0907-3 \\
\hline Type & article (author version) \\
\hline File Information & Wetlands_37(4)_741-751.pdf \\
\hline
\end{tabular}

Instructions for use 


\title{
Effects of Drainage on Open-water mire pools: Open water shrinkage and Vegetation change of Pool plant communities
}

\author{
Ahyoung Lee ${ }^{1} \cdot$ Hiroko Fujita $^{2} \cdot$ Haruki Kobayashi $^{3}$ \\ 1 Graduate School of Agriculture, Hokkaido University, North 9, West 9, Kita-ku, \\ Sapporo 060-8589, Japan \\ 2 Botanic Garden, Field Science Center for Northern Biosphere, Hokkaido University, \\ North 3, West 8, Chuo-ku, Sapporo 060-0003, Japan \\ 3 Forestry Affairs Division, Department of Industrial Promotion, Okhotsk General \\ Subprefectural Bureau, Hokkaido Government, North 7, West 3, Abashiri 093-8585, \\ Japan
}

Corresponding author: Ahyoung Lee

ahyoungs@abs.agr.hokudai.ac.jp

\begin{abstract}
Open-water mire pools play an important role in sustaining biodiversity. However, many mire pools have disappeared by artificial drainage all over the world. This study aimed at exploring how mire pools are changed by artificial drainage in terms of open water area and vegetation in Shizukari Mire, Hokkaido. We analyzed the changes of drainage ditches and open water of mire pools using multi-temporal aerial photographs. In order to elucidate how pool plant communities change by drainage, we analyzed the vegetation on the persisting pools and drained area of former pools. Our results indicated that most pools were lost soon after digging of ditches, and the remaining pools have shrunk by more diffuse, continued drainage effect. Due to open water loss, pool plant communities were considered to change towards the plant communities of drier conditions, comprising woody plants and non-wetland plant species. If the drainage continues, the remaining mire pools will ultimately disappear and the species composition of the mire could become more homogenous, being dominated by few species with high coverage.
\end{abstract}

Keywords Continued drainage $\cdot$ Drainage ditch $\cdot$ Mire pools $\cdot$ Open water $\cdot$ Vegetation change

\section{Introduction}


Mires have been considered as rather stable ecosystems that show slow changes in vegetation over time than any other terrestrial ecosystems (Weber 1902; Backéus 1972; Svensson 1988; Zobel 1988; Klinger 1996; Malmer et al. 1997; Rydin and Barber 2001; Gunnarsson et al. 2002). However, several studies have documented relatively large responses of mire vegetation to human-induced changes in recent decades (e.g. Lee et al. 1990; Chapman and Rose 1991; Hogg et al. 1995; Gunnarsson et al. 2000; Gunnarsson et al. 2002; Gunnasson and Flodin 2007; Mälson et al. 2008; van der Linden et al. 2008). Drainage, that is the main factor of wetland loss, is frequently linked to lowering of water table, changes in stream discharge, reduction in area of wetlands, and altered composition of vegetation and wildlife species (Skaggs et al. 1994; Spaling and Smit 1995). Furthermore, the repetitive nature and areal expansion of drainage may result in accumulation of environmental changes over time and across space (Spaling and Smit 1995). In the non-tropical world, $50 \%$ of the original peatland loss is due to drainage for agriculture, and 30\% is due to drainage for forestry (Joosten and Clarke 2002; Hedberg et al. 2012).

There are many previous studies about effects of drainage on vegetation and plant composition in wetlands, especially mires and peatlands (e.g. Vasander 1982; Heikkilä and Lindholm 1995a, b; Laine et al. 1995; Minkkinen et al. 1999; Joosten and Clarke 2002; Pellerin and Lavoie 2003; Pakalnis et al. 2009; Talbot et al. 2010; Laine et al. 2011). According to these studies, drainage induces secondary succession in mire vegetation and usually enhances shrub and tree encroachment and mire vegetation are replaced by common forest species. It also hampers Sphagnum growth and facilitates the establishment of generalist species. Of the original peatland vegetation, hummock species benefit from the drainage, while species demanding prolonged inundated conditions soon disappear after the drainage.

However, there is no study that elucidates how drainage ditch affects open-water mire pools and their vegetation. Open-water pools are a common feature of many peatlands (Walker 1961; Glaser 1998), and mire pools occur in raised mire systems in both upland and lowland locations (Heathwaite and Göttlich 1993). Mire pools play an important role in sustaining biodiversity, and are regarded as hotspots for biodiversity in peatlands (Lindsay et al. 1985; Guinan et al. 1998; Poulin et al. 2002; Fontaine et al. 2007; Kilroy et al. 2007). Moreover, peatlands including pools provide numerous ecosystem services such as carbon and nutrient sinks and flood regulators (Devito and Dillon 1993; Roulet et al. 2007). In spite of their functions, many mire pools have disappeared with peatlands due to drainage. Pools are particularly vulnerable to peatland exploitation or 
conversion, and will generally not return unless measures are planned specifically for them (Mazerolle et al. 2006). Recently, as recognizing the significance of the mire pools for biodiversity, there are some studies on restoration of mire pools (e.g. Mazerolle et al. 2006; Fontaine et al. 2007; Poulin et al. 2011; Beadle et al. 2015). However, natural and newly created pools had different floristic composition, although created pools potentially provide valuable new habitat for aquatic species. The studies on restoration stressed that remaining mire pools must be preserved from human disturbances, and more knowledge about the ecology of pools through the studies for restoration is needed.

Our study aimed at exploring how mire pools are changed by artificial drainage in terms of open water area and plant communities. The first objective of this study was to ascertain surface water change of mire pools caused by drainage ditches through analysis of multi-temporal aerial photographs. The second objective was to elucidate effects of drainage on plant communities through vegetation survey on persisting pools and drained area of former pools. We show how pool plant communities have changed due to drainage, and discuss how they may change henceforward if draining is continued.

\section{Methods}

\section{Study area}

Shizukari Mire $\left(42^{\circ} 34^{\prime} \mathrm{N}, 140^{\circ} 26^{\prime} \mathrm{E}\right.$, approximately 4-5 $\mathrm{m}$ a.s.l.) is located along the south-western Pacific coast of Hokkaido Island in Japan (Fig. 1). The southern limit of lowland bogs of Hokkaido is situated in the southwest part of the island, somewhat further north than the line suggested by the temperature conditions (Wolejko and Ito 1986), and this area is the southernmost site with lowland bog vegetation in Hokkaido. The mean annual temperature (1978-2015) at the nearest meteorological station $(6.3 \mathrm{~km}$ distant from the mire, $10 \mathrm{~m}$ a.s.1.) is $7.4^{\circ} \mathrm{C}$ and mean annual precipitation is $1277 \mathrm{~mm}$ (Japan Meteorological Agency 2016). Summers have foggy days with cover of sea fog from the Pacific Ocean (Fujita and Tachibana 1998).

Shizukari Mire was designated as a national natural monument in 1922 because it was a typical well-developed Sphagnum bog, and had high richness of bog plant species (Yoshii and Kudo 1926). There were a lot of bog ponds and pools in Shizukari Mire, and many floating islands were found on a largest pond between sand dunes (Tatewaki 
1924; Yoshii and Kudo 1926). Various plant community types were found at the Sphagnum lawn and hollow, poor or rich fen, alder and ash swamp forest (Tatewaki 1924; Yoshii and Kudo 1926). The area of this mire was approximately 263 ha (excluding coastal dune part), calculated from 1/50000 topographical map of the Geospatial Information Authority of Japan issued in 1917 (Fujita and Tachibana 1998) (Fig. 2a). Although this mire had a beautiful landscape and high scientific value, it lost its status as the national natural monument in 1951 for the national policy after World War II. Simultaneously, the mire was rapidly developed and had been converted into agricultural land. Consequently, the area of the current remaining mire part is about 34 ha (Fujita and Tachibana 1998) (Fig. 2a). Most of the ponds, pools, and floating islands had disappeared, and most area of peatlands had been lost, because all the five rivers flowing into the former mire were directly connected to the drainage ditches. The current remaining mire is small part of the center portion of the former bog and includes some pool vegetation, and the surroundings are roads, drainage ditches, woodlots and agricultural lands (Figs. 2a, c). This mire is a private property owned by many owners, and no conservation activities or related policies have been conducted. Nevertheless, this mire has been recently listed as one of the "Important wetlands in Japan", because it is valuable habitat for various species established in the coastal plain (Ministry of the Environment of Japan 2016).

\section{Analysis of multi-temporal aerial photographs}

We analyzed multi-temporal aerial photographs from 1947, 1965, 1976 and 2007 (black and white pictures of 1947, 1965 and color pictures of 1976, 2007) by using the software ArcMap 10.1 in ArcGIS (ESRI 2013). We decided the analysis range (122.6 ha) by comparing the changes of open water between 1947 and 2007 (Fig. 2b), and then created polygons of open water area and lines of drainage ditches from the four aerial photographs in the range respectively. For analyzing the changes of the drainage ditches and open water area, we calculated the total length of the lines and the total area of the polygons respectively using ArcGIS.

In order to analyze the changes in a higher spatial resolution, we divided the range into $5 \mathrm{~m} \times 5 \mathrm{~m}$ mesh; the polygons of open water area were also divided into $5 \mathrm{~m} \times 5 \mathrm{~m}$ mesh by using the 'Intersect' tool from the analysis toolbox as overlap with the range's mesh. We defined open water grid cell as a grid cell that contains even a little area of open water. We categorized the grid cells into four groups depending on when their open water had disappeared. Water grid cells 1 (WG 1) were grid cells that lost their 
open water during 1947-1965. Water grid cells 2 (WG 2) and water grid cells 3 (WG 3) were those that lost their open water during 1965-1976 and 1976-2007, respectively. Water grid cells 4 (WG 4) were grid cells that are existent until 2007. We calculated the distance to the nearest drainage ditch from the center of the WGs using ArcGIS, and also calculated the mean distance to the nearest ditch from each WG.

\section{Vegetation survey and analysis}

In order to clarify the impact of open water loss on vegetation of the mire pools, we randomly selected total 75 survey points of the persisting pools and drained area of former pools by comparing two aerial photographs (1947 and 2007) using the software ArcMap 10.1 in ArcGIS. We surveyed the vegetation on the 75 survey points $(2 \mathrm{~m} \times 2$ $m$ quadrat) with the phytosociological method (Braun-Blanquet 1964) in the summers of 2012 and 2013. The 75 survey points were mapped using GPS. We conducted clustering of the vegetation data for grouping plant communities, and then speculated the vegetation changes among the plant communities based on their floristic composition.

To demonstrate floristic changes among the plant communities in detail, we analyzed the vegetation data by dividing total plant species into four categories according to their plant life-forms and habitat characteristics. These categories are aqua, herb, tree, and bryo. The 'aqua' category refers to aquatic plants including emergent, floating-leaved, submerged, free-floating plants (Kadono 2014). The 'herb' category refers to herbaceous plants including herbs, grasses, and ferns except for aquatic herbaceous plants. The 'tree' category refers to woody plants including vines, shrubs and trees. The 'bryo' refers to bryophyte. Moreover, the vascular plants were also sorted into wetland or non-wetland plant species termed by Wetland plant database in Hokkaido (Suzuki et al. 2016). The nomenclature of all plant species followed the Japanese scientific name index (Y list) based on the most recent version of the Angiosperm Phylogeny Group classification (APG III) (Yonekura and Kajita 2015) for the scientific names of vascular plants and bryophytes. We calculated the mean number of species of four plant categories with the number of wetland and non-wetland plant species in each plant community.

In order to identify the impact of drainage on the plant communities, we calculated the distance to the nearest drainage ditch from the 75 survey points using ArcGIS, and also calculated the mean distance to the nearest ditch from each plant community. Using the water grid cells which include the 75 survey points, we calculated the proportion of 
the WGs in each plant community.

\section{Data analysis}

The Kruskal-Wallis test was used to test difference in the mean distance to the nearest ditch from each WG, and the multiple comparison test after Kruskal-Wallis was used to ascertain significance between the WGs $(\mathrm{p}<0.05)$ using the function kruskalmc (Siegel and Castellan 1988) available in the package pgirmess (Giraudoux 2015) of the $R$ software ver. 3.1.3 (R Core Team 2013). The original species cover-abundance values of the Braun-Blanquet scale were transformed by the 1-9 Ordinal Transform Scale (van der Maarel 1979). Cluster analysis was conducted for grouping the survey plots using a Bray-Curtis similarity measurement and flexible beta linkage $(\beta=-0.25)$, and indicator species analysis was applied to calculate indicator values for all species and their significances for the plant communities. These analysis were conducted using packages cluster (Maechler et al. 2015), indicspecies (De Cáceres and Jansen 2015), vegan (Oksanen et al. 2015), and labdsv (Roberts 2015) of the R software, and all other statistical tests were also performed using R. The Kruskal-Wallis test was also used to test the difference in the mean distance to the nearest ditch from each plant community, and the multiple comparison test after Kruskal-Wallis was used to find out significances between the plant communities $(\mathrm{p}<0.05)$.

\section{Results}

\section{Chronological change of total length of drainage ditches and total area of open water}

In the analysis of multi-temporal aerial photographs, the total length of the drainage ditches had increased over time, whereas the total area of open water had decreased (Fig. $3)$. There were no drainage ditches in 1947. However since the mire lost its status as the national natural monument in 1951, drainage ditches had increased rapidly to $37.3 \mathrm{~km}$ for the conversion of agricultural land in Period 1 (1947-1965). As a result, the total area of open water had declined remarkably from 34.28 ha to 3.87 ha. During Period 2 (1965-1976), there was less considerable change than Period 1; however, drainage ditches had been continuously dug and increased from $37.3 \mathrm{~km}$ to $43.71 \mathrm{~km}$, and open 
water area had been lost from 3.87 ha to 1.7 ha. During Period 3 (1976-2007), although the total length of the drainage ditches decreased from $43.71 \mathrm{~km}$ to $35.93 \mathrm{~km}$, the total area of open water had still declined from 1.7 ha to 1.02 ha marginally.

In the analysis of open water grid cells, the multiple comparison test after Kruskal-Wallis revealed that there was no significant difference in the mean distance to the nearest ditch between WG 1 and WG 2, while all other pairwise comparisons showed significant differences (Fig. 4). WG 1 and WG 2 were much closer to the drainage ditch than WG 3 and WG 4, while WG 4 was furthermost to the drainage ditch on average. The mean distance to the nearest ditch from WG 1 and WG 2 were approximately $20 \mathrm{~m}$, WG 3 was approximately $46 \mathrm{~m}$, and WG 4 was approximately 72 $m$ on average.

\section{Division of plant communities and the distance to the nearest ditch from each plant community}

In the 75 survey plots, a total of 56 plant species were recorded. The plant communities were divided into four groups by clustering the vegetation data, Nymphaea tetragonaMenyanthes trifoliata community ( $N-M, 17$ plots), Menyanthes trifoliata Rhynchospora alba community ( $M-R, 13$ plots), Rhynchospora alba - Moliniopsis japonica community $(R-M, 25$ plots), and Moliniopsis japonica - Solidago virgaurea subsp. leiocarpa community ( $M-S, 20$ plots) (Table 1$)$. The $N-M$ was pool vegetation consisting mainly of Species groups A and B. This community was composed mainly of aquatic plants like Brasenia schreberi, Nymphaea tetragona, Schoenoplectus hotarui, Menyanthes trifoliata. The $M-R$ was transitional vegetation between pool and drained area of former pool consisting mainly of Species groups B and C, including a few elements of Species group D. This community was composed mainly of hollow vegetation including Rhychospora alba, Utricularia uliginosa, Juncus papillosus and a few elements of aquatic plants. The $R-M$ was weakly drained area of former pool consisting mainly of Species groups C, D, and E. This community was composed mainly of hollow and lawn vegetation. The $M-S$ was more strongly drained area of former pool consisting mainly of Species groups D and E, including a few elements of Species group C. This community was composed mainly of lawn vegetation and little elements of hollow vegetation.

From the division of plant categories (Fig. 5), the $N-M$ consisted mostly of aquatic plants (aqua), little herbaceous plants (herb), and a very few woody plants (tree), but all the plants were wetland plant species. The $M-R$ consisted mostly of herb, little aqua, 
and a very few tree. This community was composed almost entirely of wetland plant species, but there were a very few non-wetland plant species in the herb. The $R-M$ consisted mostly of herb and little aqua and tree, and a very few bryophyte (bryo). This community was almost wetland plant species but a very few non-wetland plant species in the herb and tree. The $M-S$ consisted mostly of herb and tree, little aqua, and a very few bryo. This community was almost wetland plant species, but a very few non-wetland plant species in the herb and tree.

With regard to the distance to the nearest ditch from each plant community (Fig. 6), the $N-M$ was farther away from drainage ditches, whereas the other three plant communities $(M-R, R-M$, and $M-S)$ associated with drained area of former pool were closer to drainage ditches. There were significant differences between the distance to the nearest ditch from $N-M$ and those from $M-R, R-M$, and $M-S$, but there were no significant differences between the distances to the nearest ditch from $M-R, R-M$, and $M-S$.

With regard to the proportion of WGs which include the survey points in each plant community (Fig. 7), the survey points of $N-M$ (17 points) were included only in WG 4. The 3, 6, 3, 1 survey points of $M-R$ (13 points) were included in WG 1 , WG 2, WG 3, and WG 4, respectively. The 16, 5, 4 survey points of $R-M$ (25 points) were included in WG 1 , WG 2, and WG 3, respectively. The 8, 9, 2, 1 survey points of $M-S$ (20 points) were included in $\mathrm{WG} 1, \mathrm{WG} 2, \mathrm{WG} 3$, and $\mathrm{WG} 4$, respectively.

\section{Discussion}

\section{Open water shrinkage of mire pools caused by drainage ditches}

Fens and bogs, and mire pools formed in peatlands were destroyed by agriculture and large-scale national projects undertaken during the latter 20th century in many countries; pool ecosystems have been damaged seriously by various human activities (National Research Council 1992; Verhoeven et al. 1996; Mitsch and Gosselink 2015). Our result shows the fact that many mire pools have artificially disappeared by a fast development for agriculture. There were striking increases of drainage ditches during Period 1 and Period 2, whereas there were absolutely no drainage ditches before Period 1 (Fig. 3). This is supposed that the open water of the mire pools declined remarkably until 1970s in Shizukari Mire. In Hokkaido, extensive agricultural development and urbanization have progressed following World War II (Nakamura and Yamada 2005). 
Notably in the west and central parts of Hokkaido including the Shizukari Mire, losses of wetlands were severe between the 1950s and 1970s (Fujita et al. 2009).

Drainage was caused by ditches dug during Period 1 and Period 2 (Fig. 3), and the open water lost during Period 1 and Period 2 (WG 1 and WG 2) were approximately 20 $\mathrm{m}$ distant to the nearest ditch (Fig. 4). Our interpretation is that most of the loss of mire pools in the Shizukari Mire took place soon after digging of ditches. Several Canadian studies that looked at the effects of ditching on lowering the water table in peatlands have suggested that drainage is most effective within ten to $15 \mathrm{~m}$ of a ditch (Tóth and Gillard 1988; Belleau et al. 1992; Roy et al. 2000). Moreover, most of the drying effect associated with a drainage ditch in bogs usually occurs within 25m (Hillman 1992; Rothwell et al. 1996).

However, depending on the composition and the structure of the peat, the drainage ditches can impact great distances from drainage installations (Landry and Rochefort 2012). It should be noted that during Period 3 despite decline of total length of drainage ditches due to aging and lack of maintenance of the ditches, open water area had been slightly decreased continuously (Fig. 3). In addition, the open water lost during Period 3 and existing open water (WG 3 and WG 4) were on average $46 \mathrm{~m}$ and $72 \mathrm{~m}$ distant to the nearest ditch, respectively (Fig. 4). Boelter (1972) concluded that if the peat is fibric, the water table more than $50 \mathrm{~m}$ away from a drainage ditch can be lowered. Moreover, drainage is a source of cumulative environmental change because of its repetitive and expansive nature (Spaling and Smit 1995). The cumulative nature of drainage is apparent in increasing drainage density over time (Spaling and Smit 1995). These suggest that remaining open water in the mire pools could shrink continuously due to existing drainage ditches if protections are not implemented.

Our results indicate that immediate drainage from near the ditch by digging ditches is most effective for the water table less than $20 \mathrm{~m}$ away from the drainage ditches in short-term, and moreover, water table more than $50 \mathrm{~m}$ away from the drainage ditches is also lowered by continued drainage effect in longer-term. In conclusion, digging ditches not only cause immediate drainage but also continued drainage effect.

\section{Vegetation change of pool plant communities caused by open water loss}

From our results, we could suppose the sequence of vegetation change of pool plant community. It is suggested that open water loss caused the vegetation change mainly from the pool plant communities $(N-M)$ to the plant communities of drained area of former pools $(M-R, R-M$, and finally to $M-S)$. The aquatic plants were lost, and 
wetland plant species except the aquatic plants drastically increased from $N-M$ to $M-$ $R, R-M$, but declined from $R-M$ to $M-S$ (Fig. 5). It is considered that wetland plant species could occupy and increased in the area because the drained area of former pool remained under wet condition. However, as the drainage effect continued, the woody plants gradually increased and non-wetland plant species also appeared from $M-R$ to $R$ $-M$ and $M-S$ (Fig. 5). It is considered that intensifying drainage caused the occurrence of woody plants and decline of wetland plant species of herbaceous plants. Lowered water table due to drainage results in vegetation typical of drier conditions than natural (Howie et al. 2009). The plant species living on wet surfaces are the first to disappear, while hummock-dwelling species (e.g. dwarf shrubs) may even benefit from drainage (Sarasto 1961; Eurola et al. 1984).

In our interpretation, this change from $N-M$ to $M-R, R-M$, and finally to $M-S$ was more likely the closer to a drainage ditch (Fig. 6). In particular, $R-M$ and $M-S$, which are characterized by disappearance of aquatic plants except for Phragmites australis and invasion of woody plants, were even nearer to the drainage ditch than others. On the other hand, the plant community of persisting pools $(N-M)$ was farther than any other communities of drained area of former pools $(M-R, R-M$, and $M-S)$ (Fig. 6). These results indicate that the drier soil resulting from lower water tables following drainage has brought about distinct changes in the types of vegetation and the land in the immediate vicinity of ditches is more effectively drained than land some distance away (Frolik 1941). This differential efficiency in drainage brings about zonation in the vegetation on the various parts of a drained area, the more advanced stages lying in closer proximity to the ditches (Frolik 1941).

However, the pool plant community does not necessarily change in the sequence from $N-M$ to $M-R, R-M$, and $M-S$. There were not significant differences among the distances to the nearest ditch from the plant communities of drained area of former pools $(M-R, R-M$, and $M-S)$ (Fig. 6). In addition, there were no large differences in the proportions of WGs which include the points of vegetation survey among the $M-R$, $R-M$, and $M-S$, although the proportions of WG 1 and WG 2 were very large (Fig. 7). These results indicate that the rate of vegetation change may be different, because the rate of drainage is different depending on the composition and the structure of the peat soil.

Our results about vegetation change also suggest that, without any protections, the vegetation change towards woody vegetation and loss of aquatic vegetation could be continued, because most plant communities associated with the mire pools including the drained area of former pools are located less than $100 \mathrm{~m}$ away from the drainage ditches 
(Fig. 6). Some previous studies said that effects of drainage on bog water table, and indirect effects on vegetation communities are rarely perceptible at distances exceeding $100 \mathrm{~m}$ away from a ditch (Hillman 1992; Poulin et al. 1999; Roy et al. 2000). In other words, effects of drainage on vegetation communities can be influential at distances less than $100 \mathrm{~m}$ away from a ditch.

\section{Conclusions}

This study identified the effects of drainage on open-water mire pools. Most open water of mire pools was lost soon after digging of ditches. Moreover, remaining open water also has shrunk by more diffuse, continued drainage effect. The open water loss caused the vegetation change of pool plant communities. These results were related to the distance from the ditch. The closer to the drainage ditch, these changes became severer.

This study might be the first study focusing on not only the surface hydrological dynamics of open water of the mire pools affected by drainage but also on the vegetation change of the mire pools. We demonstrated a negative effect of drainage and realized that we must protect the remaining mire and mire pools from drainage in any way. If the remaining mire pools disappear due to continued drainage effect, the mire vegetation will become more homogenous and the mire will lose its function as the mire ecosystem. Although restoration of disappeared mire pools is important, it is more significant to preserve the remaining mire pools from continued drainage effect.

\section{Acknowledgements}

This study was financially supported by the Environment Research and Technology Development Fund (S9) of the Ministry of the Environment, Japan (http://s9.conservationecology.asia). We thank gratefully for support of the Ministry of the Environment.

\section{References}

Backéus I (1972) Bog vegetation re-mapped after sixty years. Oikos 23:384-393

Beadle JM, Brown LE, Holden J (2015) Biodiversity and ecosystem functioning in 
natural bog pools and those created by rewetting schemes. WIREs Water 2:65-84

Belleau P, Plamondon AP, Lagacé R, Pépin S (1992) Hydrodynamique d'une pessière noire drainée. Canadian Journal of Forest Research 22:1063-1070

Boelter DH (1972) Water table drawdown around an open ditch in organic soils. Journal of Hydrology 15:329-340

Braun-Blanquet J (1964) Pflanzensoziologie: grundzüge der vegetationskunde. 3rd edn. Springer, Vienna, Austria

Chapman S, Rose R (1991) Changes in the vegetation at Coom Rigg Moss National Nature Reserve within the period 1958-86. Journal of Applied Ecology 28:140153

De Cáceres M, Jansen F (2015) Indicspecies: Relationship between species and group of sites. R package version 1.7.5. http://cran.r-project.org/package=indicspecies

Devito KJ, Dillon PJ (1993) The influence of hydrologic conditions and peat oxia on the phosphorus and nitrogen dynamics of a conifer swamp. Water Resource Research 29:2675-2685

ESRI (2013) ArcGIS desktop. Environmental Systems Research Institute, Redlands, USA

Eurola S, Hicks S, Kaakinen E (1984) Key to Finnish mire types. In: Moore PD (ed) European Mires, Academic Press, London, UK, pp 11-117

Fontaine N, Poulin M, Rochefort L (2007) Plant diversity associated with pools in natural and restored peatlands. Mires and Peat 2:1-17

Frolik AL (1941) Vegetation on the peat lands of Dane County, Wisconsin. Ecological Monographs 11:117-140

Fujita H, Igarashi Y, Hotes S, Takada M, Inoue T, Kaneko M (2009) An inventory of the mires of Hokkaido, Japan - their development, classification, decline, and conservation. Plant Ecology 200:9-36

Fujita H, Tachibana H (1998) Vegetation and land use changes of Shizukari mire, the former national natural monument of southwest Hokkaido. Vegetation Science 15:7-17 (in Japanese)

Giraudoux P (2015) Pgirmess: data analysis in ecology. R package version 1.6.0. http://CRAN.R-project.org/package=pgirmess

Glaser PH (1998) The distribution and origin of mire pools. In: Standen V, Tallis JH, Meade R (eds) Patterned mires and mire pools, British Ecological Society, London, UK, pp 4-25

Guinan L, O’Connor A, O’Connor M, Skeffington MS (1998) Small-scale vegetation patterns on a raised bog, Co. Offaly, and an Atlantic blanket bog, Co. Galway, 
Ireland. In: Standen V, Tallis JH, Meade R (eds) Patterned mires and mire pools, British Ecological Society, London,UK, pp 66-86

Gunnarsson U, Flodin L-Å (2007) Vegetation shifts towards wetter site conditions on oceanic ombrotrophic bogs in southwestern Sweden. Journal of Vegetation Science 18:595-604

Gunnarsson U, Håkan R, Hugo S (2000) Diversity and pH changes after 50 years on the boreal mire Skattlössbergs Stormosse, Central Sweden. Journal of Vegetation Science 11:277-286

Gunnarsson U, Malmer N, Rydin H (2002) Dynamics or constancy in Sphagnum dominated mire ecosystems? A 40-year study. Ecography 25:685-704

Heathwaite AL, Göttlich K (1993) Mires: process, exploitation and conservation, John Wiley \& Sons Ltd., London, UK, pp 17

Hedberg P, Kotowski W, Saetre P, Mälson K, Rydin H, Sundberg S (2012) Vegetation recovery after multiple-site experimental fen restorations. Biological Conservation 147:60-67

Heikkilä H, Lindholm T (1995a) The basis of mire restoration in Finland. In: Wheeler BD, Shaw SC, Fojt WJ, Robertson RA (eds) Restoration of temperate wetlands, John Wiley \& Sons Ltd., Chichester, England, pp 549-556

Heikkilä H, Lindholm T (1995b) The effects of mire drainage and the initial phases of mire restoration on the vegetation in the Seitseminen National Park, western Finland. Gunneria 70:221-236

Hillman GR (1992) Some hydrological effects of peatland drainage in Alberta's boreal forest. Canadian Journal of Forest Research 22:1588-1596

Hogg P, Squires P, Fitter AH (1995) Acidification, nitrogen deposition and rapid vegetational change in a small valley mire in Yorkshire. Biological Conservation $71: 143-153$

Howie SA, Whitfield PH, Hebda RJ, Munson TG, Dakin RA, Jeglum JK (2009) Water table and vegetation response to ditch blocking: restoration of a raised bog in southwestern British Columbia. Canadian Water Resources Journal 34:381-392

Japan Meteorological Agency (2016) Hakodate local meteorological office since 1872. http://www.jma-net.go.jp/hakodate-c/. Accessed 9 Apr 2016 (in Japanese)

Joosten H, Clarke D (2002) Wise use of mires and peatlands - background and principles including a framework for decision-making. International Mire Conservation Group and International Peat Society, Saarijärvi, Finland

Kadono Y (2014) Aquatic plants of Japan. Bunichi-sougou-shuppan, Tokyo, Japan (in Japanese) 
Kilroy C, Biggs BJF, Vyverman W (2007) Rules for macroorganisms applied to microorganisms: patterns of endemism in benthic freshwater diatoms. Oikos 116:550-564

Klinger LF (1996) The myth of the classic hydrosere model of bog succession. Arctic and Alpine Research 28:1-9

Laine AM, Leppälä M, Tarvainen O, Päätalo M-L, Seppänen R, Tolvanen A (2011) Restoration of managed pine fens: effect on hydrology and vegetation. Applied Vegetation Science 14:340-349

Laine J, Vasander H, Laiho R (1995) Long-term effects of water level drawdown on the vegetation of drained pine mires in southern Finland. Journal of Applied Ecology 32:785-802

Landry J, Rochefort L (2012) The drainage of peatlands: impacts and rewetting techniques. Peatland Ecology Research Group, Université Laval, Québec, Canada

Lee JA, Baxter R, Emes MJ (1990) Responses of Sphagnum species to atmospheric nitrogen and sulphur deposition. Botanical Journal of the Linnaean Society 104:255-265

Lindsay RA, Riggall J, Burd F (1985) The use of small-scale surface patterns in the classification of British peatlands. Aquilo Series Botanica 21:67-79

Maechler M, Rousseeuw P, Struyf A, Hubert M, Hornik K (2015) Cluster: cluster analysis basics and extensions. $\mathrm{R}$ package version 2.0.1. https://cran.r-project.org/web/packages/cluster/index.html

Malmer N, Svensson G, Wallén B (1997) Mass balance and nitrogen accumulation in hummocks on a South Swedish bog during the late Holocene. Ecography 20:535549

Mälson K, Backéus I, Rydin H (2008) Long-term effects of drainage and initial effects of hydrological restoration on rich fen vegetation. Applied Vegetation Science 11:99-106

Mazerolle MJ, Poulin M, Lavoie C, Rochefort L, Desrochers A, Drolet B (2006) Animal and vegetation patterns in natural and man-made bog pools: implications for restoration. Freshwater Biology 51:333-350

Ministry of the Environment of Japan https://www.env.go.jp/nature/important_wetland/wetland/w071.html. Accessed on 8 December 2016 (in Japanese)

Minkkinen K, Vasander H, Jauhiainen S, Karsisto M, Laine J (1999) Post-drainage changes in vegetation composition and carbon balance in Lakkasuo mire, Central Finland. Plant and Soil 207:107-120 
Mitsch WJ, Gosselink JG (2015) Wetlands, 5th edn. John Wiley \& Sons, New Jersey, USA

Nakamura F, Yamada H (2005) Effects of pasture development on the ecological functions of riparian forests in Hokkaido in northern Japan. Ecological Engineering 24:539-550

National Research Council (1992) Restoration of aquatic ecosystems: science, technology, and public policy. National Academy Press, Washington DC, USA

Oksanen J, Blanchet FG, Kindt R et al (2015) Vegan: community ecology package. R package version 2.3. http://CRAN.Rproject.org/package=vegan

Pakalnis R, Sendžikaitė J, Jarašius L, Avižienė D (2009) Problems of peatlands restoration after peat cutting. In: Laman NA, Grummo ND, Galanina OV, Sozinov OV, Zeliankevich NA (eds) Vegetation of mires: modern problems of classification, mapping, use and protection, Proceedings of the international theoretical and practical seminar, Minsk, Belarus, pp 33-44

Pellerin S, Lavoie C (2003) Reconstructing the recent dynamics of mires using a multitechnique approach. Journal of Ecology 91:1008-1021

Poulin M, Careau D, Rochefort L, Desrochers A (2002) From satellite imagery to peatland vegetation diversity: how reliable are habitat maps? Conservation Ecology 6:16

Poulin M, Fontaine N, Rochefort L (2011) Restoration of pool margin communities in cutover peatlands. Aquatic Botany 94:107-111

Poulin M, Rochefort L, Desrochers A (1999) Conservation of bog plant species assemblages: assessing the role of natural remnants in mined sites. Applied Vegetation Science 2:169-180

R Core Team (2013) R: a language and environment for statistical computing. R foundation for statistical computing, Vienna, Austria. http:/www.R-project.org/

Roberts DW (2015) Labdsv: ordination and multivariate analysis for ecology. R package version 1.7-0. http://ecology.msu.montana.edu/labdsv/R

Rothwell RL, Silins U, Hillman GR (1996) The effects of drainage on substrate water content at several forested Alberta peatlands. Canadian Journal of Forest Research 26:53-62

Roulet NT, Lafleur PM, Richard PJH, Moore TR, Humphreys ER, Bubier J (2007) Contemporary carbon balance and late Holocene carbon accumulation in a northern peatland. Global Change Biology 13:397-411

Roy V, Plamondon AP, Bernier PY (2000) Draining forested wetland cutovers to improve seedling root zone conditions. Scandinavian Journal of Forest Research 


\section{5:58-67}

Rydin H, Barber KE (2001) Long-term and fine-scale coexistence of closely related species. Folia Geobotanica 36:53-61

Sarasto J (1961) Über die Klassifizierung der für Walderziehung entwässerten Moore. Acta Forestalia Fennica 74:1-57

Siegel S, Castellan NJ (1988) Non parametric statistics for the behavioural sciences. Mc Graw Hill Int. Edt.

Skaggs RW, Brevé MA, Gilliam JW (1994) Hydrologic and water quality impacts of agricultural drainage. Critical Reviews in Environmental Science and Technology $24: 1-32$

Spaling H, Smit B (1995) A conceptual model of cumulative environmental effects of agricultural land drainage. Agriculture, Ecosystems \& Environment 53:99-108

Suzuki T, Fujita H, Kobayashi H, Lee A, Niimi E, Ono S (2016) Creation of a plant database and evaluation of conservation priorities in wetlands, in Hokkaido, Japan. Japanese Journal of Conservation Ecology 21:125-134 (in Japanese)

Svensson G (1988) Fossil plant communities and regeneration patterns on a raised bog in south Sweden. Journal of Ecology 76:41-59

Talbot J, Richard PJH, Roulet NT, Booth RK (2010) Assessing long-term hydrological and ecological responses to drainage in a raised bog using paleoecology and a hydrosequence. Journal of Vegetation Science 21:143-156

Tatewaki M (1924) An oecological study of the Shizukari-moor. Bachelor's thesis, Hokkaido Imperial University, Japan

Tóth J, Gillard D (1988) Experimental design and evaluation of a peatland drainage system for forestry by optimization of synthetic hydrographs. Canadian Journal of Forest Research 18:353-373

Vasander H (1982) Plant biomass and production in virgin, drained and fertilized sites in a raised bog in southern Finland. Annales Botanici Fennici 19:103-125

Verhoeven JTA, Keuter A, van Logtestjin R, van Kerkhoven MB, Wassen M (1996) Control of local nutrient dynamics in mires by regional and climatic factors: a comparison of Dutch and Polish sites. Journal of Ecology 84:647-656

van der Linden M, Vickery E, Charman DJ, van Geel B (2008) Effects of human impact and climate change during the last 350 years recorded in a Swedish raised bog deposit. Palaeogeography Palaeoclimatology Palaeoecology 262:1-31

van der Maarel E (1979) Transformation of cover-abundance values in phytosociology and its effect on community similarity. Vegetatio 39:97-114

Walker D (1961) Peat stratigraphy and bog regeneration. Proceedings of the Linnaean 
Society of London 172:29-33

Weber CA (1902) Über die vegetation und entstehung des hochmoors von Augstumal im memeldelta mit vergleichenden ausblicken auf andere hochmoore der erde. Paul Parey, Berlin, Germany

Wolejko L, Ito K (1986) Mires of Japan in relation to mire zones, volcanic activity and water chemistry. Japanese Journal of Ecology 35:575-586

Yonekura K, Kajita T (2015) BG Plants WameiGakumei Index (Y List). http://ylist.info. Accessed 8 Apr 2015 (in Japanese)

Yoshii Y, Kudo Y (1926) Investigation report on Biwase mire and Shizukari mire, Hokkaido. Natural Monuments Investigation Report, Section on Plants, Vol 5, Minister of Home Affairs, Tokyo, Japan, pp 25-38 (in Japanese)

Zobel M (1988) Autogenic succession in boreal mires - a review. Folia Geobotanica et Phytotaxonomica 23:417-445

Table 1 The species composition of four plant communities. Plant communities are named as Nymphaea tetragona - Menyanthes trifoliata community $(N-M)$, Menyanthes trifoliata - Rhynchospora alba community $(M-R)$, Rhynchospora alba Moliniopsis japonica community $(R-M)$, and Moliniopsis japonica - Solidago virgaurea subsp. leiocarpa community $(M-S)$.

\begin{tabular}{|c|c|c|c|c|c|c|}
\hline \multicolumn{3}{|c|}{ plant community } & $N-M$ & $M-R$ & $R-M$ & $M-S$ \\
\hline \multicolumn{3}{|c|}{ the total number of survey plot } & 17 & 13 & 25 & 20 \\
\hline \multicolumn{3}{|c|}{ the mean number of species / survey plot } & 5 & 9 & 15 & 13 \\
\hline $\begin{array}{l}\text { Division of } \\
\text { plant species }\end{array}$ & Family name & Species name & \multicolumn{4}{|c|}{ Frequency of plant species in each plant community } \\
\hline \multicolumn{7}{|c|}{ Species group A } \\
\hline aqua/wet & Lentibulariaceae & Utricularia japonica & $I_{+-5} * * *$ & - & - & - \\
\hline aqua/wet & Cabombaceae & Brasenia schreberi & $\mathrm{IIII}_{+-4}^{* * *}$ & - & - & - \\
\hline aqua/wet & Nymphaeaceae & Nymphaea tetragona & $\mathrm{IV}_{+-4}^{* * *}$ & $\mathrm{I}_{1}$ & - & - \\
\hline aqua/wet & Cyperaceae & Schoenoplectus hotarui & $\mathrm{IV}_{+-2}^{* * *}$ & $\mathrm{I}_{1}$ & - & - \\
\hline \multicolumn{7}{|c|}{ Species group B } \\
\hline aqua/wet & Menyanthaceae & Menyanthes trifoliata & $\mathrm{IV}_{+-3}^{* *}$ & $\mathrm{IV}_{+-2}$ & $\mathrm{I}_{+}$ & - \\
\hline \multirow[t]{2}{*}{ herb/wet } & Iridaceae & Iris laevigata & $\mathrm{IIII}_{+-3}$ & $\mathrm{IIII}_{+-1}$ & $\mathrm{IV}_{+-1}$ & $\mathrm{I}_{+-1}$ \\
\hline & & Species group C & & & & \\
\hline herb/wet & Cyperaceae & Rhynchospora alba & $\mathrm{I}_{+}$ & $\mathrm{V}_{3-4^{* * *}}$ & $\mathrm{~V}_{1-4}$ & $\mathrm{II}_{+-1}$ \\
\hline
\end{tabular}




\begin{tabular}{|c|c|c|c|c|c|c|}
\hline herb/wet & Lentibulariaceae & Utricularia uliginosa & $\mathrm{I}_{+-1}$ & $\mathrm{~V}_{+-1}^{* * *}$ & $\mathrm{IV}_{+-1}$ & $\mathrm{I}_{+}$ \\
\hline herb/wet & Cyperaceae & Rhynchospora fauriei & $\mathrm{I}_{+}$ & $\mathrm{IV}_{+-1}$ & $\mathrm{IV}_{+-4}{ }^{*}$ & $\mathrm{II}_{+-1}$ \\
\hline herb/wet & Juncaceae & Juncus papillosus & - & $\mathrm{V}_{1-2}^{* * *}$ & $\mathrm{~V}_{+-2}$ & $\mathrm{II}_{+-1}$ \\
\hline herb/wet & Orchidaceae & Pogonia japonica & - & $\mathrm{IV}_{+-1}^{* *}$ & $\mathrm{IV}_{+-1}$ & $\mathrm{II}_{+}$ \\
\hline herb/wet & Droseraceae & Drosera rotundifolia & - & $\mathrm{IIII}_{+-1}$ & $\mathrm{~V}_{+-3^{* * *}}$ & $\mathrm{IIII}_{+-1}$ \\
\hline herb/wet & Orchidaceae & Platanthera tipuloides subsp. nipponica & - & $\mathrm{II}_{+-1}$ & $\mathrm{IIII}_{+-1}^{* *}$ & $\mathrm{I}_{+}$ \\
\hline \multirow[t]{2}{*}{ herb/non } & Haloragaceae & Haloragis micrantha & - & $\mathrm{I}_{+}$ & $\mathrm{III}_{+-1}{ }^{* *}$ & $I_{+-1}$ \\
\hline & & Species group D & & & & \\
\hline herb/wet & Poaceae & Moliniopsis japonica & $\mathrm{I}_{+}$ & $\mathrm{II}_{+-2}$ & $\mathrm{~V}_{+-3}$ & $\mathrm{~V}_{+-4}{ }^{* * *}$ \\
\hline tree/wet & Ericaceae & Vaccinium oxycoccos & $\mathrm{I}_{+}$ & $\mathrm{I}_{+}$ & $\mathrm{II}_{+-1}$ & $\mathrm{IIII}_{+}^{* *}$ \\
\hline herb/wet & Cyperaceae & Carex middendorffii & - & $I_{+-1}$ & $I_{1-4}$ & $\mathrm{IV}_{+-3}^{* * *}$ \\
\hline tree/wet & Myricaceae & Myrica gale var. tomentosa & - & $\mathrm{I}_{+}$ & $\mathrm{IV}_{+-2}$ & $\mathrm{~V}_{1-3}{ }^{* * *}$ \\
\hline \multirow[t]{2}{*}{ herb/wet } & Rosaceae & Sanguisorba tenuifolia & - & $\mathrm{I}_{+}$ & $\mathrm{IV}_{+}$ & $\mathrm{V}_{+-1}^{* * *}$ \\
\hline & & Species group $\mathbf{E}$ & & - & & \\
\hline herb/wet & Violaceae & Viola verecunda var. semilunaris & - & - & $\mathrm{IV}_{+-1}^{* * *}$ & $\mathrm{III}_{+}$ \\
\hline herb/wet & Campanulaceae & Lobelia sessilifolia & - & - & $\mathrm{IV}_{+-2}^{* * *}$ & $\mathrm{II}_{+-1}$ \\
\hline herb/wet & Asteraceae & Solidago virgaurea subsp. leiocarpa & - & - & $\mathrm{IIII}_{+}$ & $\mathrm{V}_{+-1}^{* * *}$ \\
\hline tree/wet & Aquifoliaceae & Ilex crenata var. radicans & - & - & $I_{+-1}$ & $\mathrm{IIII}_{+-5}{ }^{* * *}$ \\
\hline \multirow[t]{2}{*}{ tree/wet } & Hydrangeaceae & Hydrangea paniculata & - & $\mathrm{I}_{+}$ & $\mathrm{I}_{+}$ & IIII $_{+-2}^{* * *}$ \\
\hline & & Others & & - & & \\
\hline aqua/wet & Poaceae & Phragmites australis & $\mathrm{V}_{+-2}$ & $\mathrm{~V}_{+-2}$ & $\mathrm{~V}_{+-3}$ & $\mathrm{~V}_{+-3}$ \\
\hline tree/wet & Betulaceae & Alnus japonica & - & - & - & $\mathrm{I}_{+}$ \\
\hline aqua/wet & Cyperaceae & Eleocharis congesta & $\mathrm{I}_{+}$ & - & $\mathrm{I}_{+}$ & - \\
\hline herb/wet & Cyperaceae & Carex limosa & $I_{+-2}$ & $\mathrm{I}_{1}$ & $\mathrm{I}_{1}$ & - \\
\hline herb/wet & Lycopodiaceae & Lycopodium inundatum & $\mathrm{I}_{+}$ & $\mathrm{I}_{1}$ & $\mathrm{II}_{+-2^{*}}$ & $\mathrm{I}_{+}$ \\
\hline tree/non & Taxaceae & Taxus cuspidata & - & - & $\mathrm{I}_{+}$ & - \\
\hline herb/wet & Celastraceae & Parnassia palustris var. palustris & - & - & $\Pi_{+-1}^{*}$ & $\mathrm{I}_{+-1}$ \\
\hline herb/wet & Orchidaceae & Epipactis thunbergii & - & - & $\mathrm{I}_{+}$ & $\mathrm{I}_{1}$ \\
\hline tree/wet & Ericaceae & $\begin{array}{l}\text { Ledum palustre subsp. diversipilosum } \\
\text { var. diversipilosum }\end{array}$ & - & - & - & $\mathrm{I}_{+}$ \\
\hline herb/wet & Primulaceae & Lysimachia vulgaris var. davurica & - & - & - & $\mathrm{I}_{+}$ \\
\hline herb/wet & Cyperaceae & Eleocharis wichurae & - & - & - & $\mathrm{I}_{1}$ \\
\hline herb/non & Poaceae & Miscanthus sinensis & - & - & $\mathrm{I}_{+}$ & $\mathrm{I}_{1}$ \\
\hline herb/wet & Asparagaceae & Hosta sieboldii var. rectifolia & - & - & $\mathrm{I}_{+}$ & $\mathrm{I}_{+-1}$ \\
\hline tree/non & Anacardiaceae & Toxicodendron radicans subsp. orientale & - & - & $\mathrm{I}_{+}$ & $\mathrm{I}_{+}$ \\
\hline
\end{tabular}




\begin{tabular}{|c|c|c|c|c|c|c|}
\hline herb/wet & Thelypteridaceae & Thelypteris nipponica & - & - & - & $\mathrm{I}_{+-1}$ \\
\hline herb/wet & Orchidaceae & Spiranthes sinensis var. amoena & - & - & $\mathrm{I}_{+}$ & - \\
\hline herb/wet & Thelypteridaceae & Thelypteris palustris & - & - & - & $\mathrm{I}_{+}$ \\
\hline tree/wet & Ericaceae & Andromeda polifolia & - & - & - & $\mathrm{I}_{+}$ \\
\hline herb/wet & Lamiaceae & Lycopus maackianus & - & - & $I_{+-1}$ & $\mathrm{I}_{+}$ \\
\hline herb/non & Asteraceae & Eupatorium makinoi & - & - & $\mathrm{I}_{+}$ & - \\
\hline herb/wet & Scheuchzeriaceae & Scheuchzeria palustris & - & - & - & $\mathrm{I}_{+}$ \\
\hline herb/wet & Gentianaceae & Gentiana triflora var. japonica & - & - & $\mathrm{II}_{+}^{*}$ & $\mathrm{I}_{+}$ \\
\hline herb/wet & Hypericaceae & Triadenum japonicum & - & - & $\mathrm{I}_{+}$ & $\mathrm{I}_{+-1}$ \\
\hline herb/wet & Cyperaceae & Carex michauxiana subsp. asiatica & - & - & $\mathrm{I}_{1}$ & $\mathrm{I}_{2}$ \\
\hline tree/wet & Ericaceae & Chamaedaphne calyculata & - & - & - & $\mathrm{I}_{+-1}$ \\
\hline tree/non & Anacardiaceae & Toxicodendron trichocarpum & - & - & - & $\mathrm{II}_{+-3}^{* * *}$ \\
\hline herb/wet & Osmundaceae & Osmunda cinnamomea subsp. asiatica & - & - & $\mathrm{I}_{+}$ & $\mathrm{II}_{+-3}^{* *}$ \\
\hline herb/wet & Cyperaceae & Eriophorum vaginatum subsp. fauriei & - & - & $I_{+-1}$ & $\mathrm{I}_{+-1}$ \\
\hline herb/wet & Dennstaedtiaceae & Pteridium aquilinum subsp. japonicum & - & - & - & $\mathrm{I}_{+-2}$ \\
\hline bryo/spha & Sphagnaceae & Sphagnum papillosum & - & - & - & $\mathrm{I}_{5}$ \\
\hline bryo/spha & Sphagnaceae & Sphagnum compactum & - & - & $\mathrm{I}_{3}$ & - \\
\hline bryo/moss & Hypnaceae & Callicladium haldanianum & - & - & - & $\mathrm{I}_{1}$ \\
\hline
\end{tabular}

Significances of indicator species are marked with asterisks : *** $\mathrm{p}<0.001,{ }^{* *} \mathrm{p}<0.01$, $* \mathrm{p}<0.05$, Frequency of species in each plant community: I (sparse) $=1-20 \%$, II $($ occasional $)=21-40 \%$, III (frequent $)=41-60 \%$, IV $($ constant $)=61-80 \%, \mathrm{~V}($ constant $)$ $=81-100 \%$, Braun-Blanquet's cover-abundance scale: $+=$ a few individuals $(<10 \%), 1$ $=$ numerous individuals $(<10 \%), 2=10-25 \%, 3=25-50 \%, 4=50-75 \%, 5=75-100 \%$.

\section{Figure Captions}

Fig. 1 Location of the study area (Shizukari Mire in Hokkaido Island, Northern Japan).

Fig. 2 The ranges of Shizukari Mire. (a) the mire area in 1917 (pristine mire) and in 1996 (remaining mire) and the analysis ranges of multi-temporal aerial photographs and vegetation survey, (b) the analysis range of multi-temporal aerial photographs in aerial photo of 1947, (c) the range of remaining mire in aerial photo of 2007 (a: Digital Topographic Map (Tile) published by Geospatial Information Authority of Japan; the lines after Fujita and Tachibana (1998), b and c: 1947 and 2007 aerial orthophotographs authorized by Geospatial Information Authority of Japan). 
Fig. 3 Chronological change of total length of drainage ditches and total area of open water (Period 1: 1947-1965, Period 2: 1965-1976, Period 3: 1976-2007).

Fig. 4 The distance to the nearest drainage ditch from each group of water grid cells (WG) (WG 1: grid cells that lost open water during 1947-1965, WG 2: grid cells that lost open water during 1965-1976, WG 3: grid cells that lost open water during 19762007, WG 4: grid cells that are still existing in 2007). Different letters (a, b, c) indicate significant differences between the groups of water grid cells $(W G s)(p<0.05)$.

Fig. 5 Plant composition of plant communities divided into four plant categories with division of wetland plant species or non-wetland plant species (aqua: category of aquatic plants including floating, floating leaved, and emergent plants, herb: category of herbaceous plants including herbs, grasses, and ferns except for aquatic herbaceous plants, tree: category of woody plants including shrubs, vines, and trees, bryo: category of bryophyte). (a) Nymphaea tetragona - Menyanthes trifoliata community $(N-M)$, (b) Menyanthes trifoliata - Rhynchospora alba community $(M-R)$, (c) Rhynchospora alba - Moliniopsis japonica community $(R-M)$, and (d) Moliniopsis japonica - Solidago virgaurea subsp. leiocarpa community $(M-S)$.

Fig. 6 The distance to the nearest drainage ditch from each plant community $(N-M$ : Nymphaea tetragona - Menyanthes trifoliata community, $M-R$ : Menyanthes trifoliata - Rhynchospora alba community, $R$ - M: Rhynchospora alba - Moliniopsis japonica community, $M-S$ : Moliniopsis japonica - Solidago virgaurea subsp. leiocarpa community). Different letters $(\mathrm{a}, \mathrm{b})$ indicate significant differences between the plant communities $(\mathrm{p}<0.05)$.

Fig. 7 The proportion of WGs which include the survey points in each plant community ( $N-M$ : Nymphaea tetragona - Menyanthes trifoliata community, $M-R$ : Menyanthes trifoliata - Rhynchospora alba community, $R-M$ : Rhynchospora alba - Moliniopsis japonica community, $M-S$ : Moliniopsis japonica - Solidago virgaurea subsp. leiocarpa community; WG 1: grid cells that lost open water during 1947-1965, WG 2: grid cells that lost open water during 1965-1976, WG 3: grid cells that lost open water during 1976-2007, WG 4: grid cells that are still existing in 2007). 


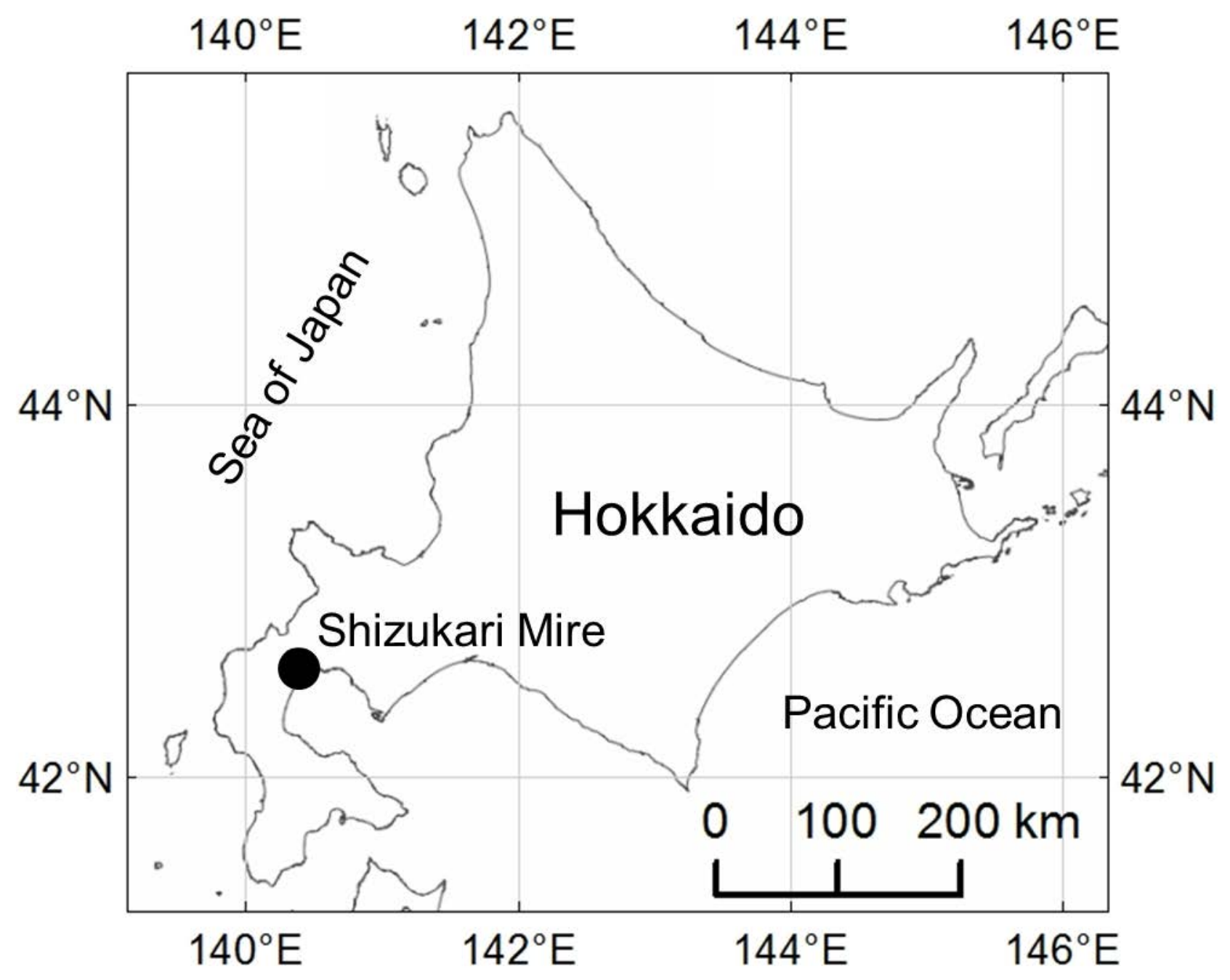




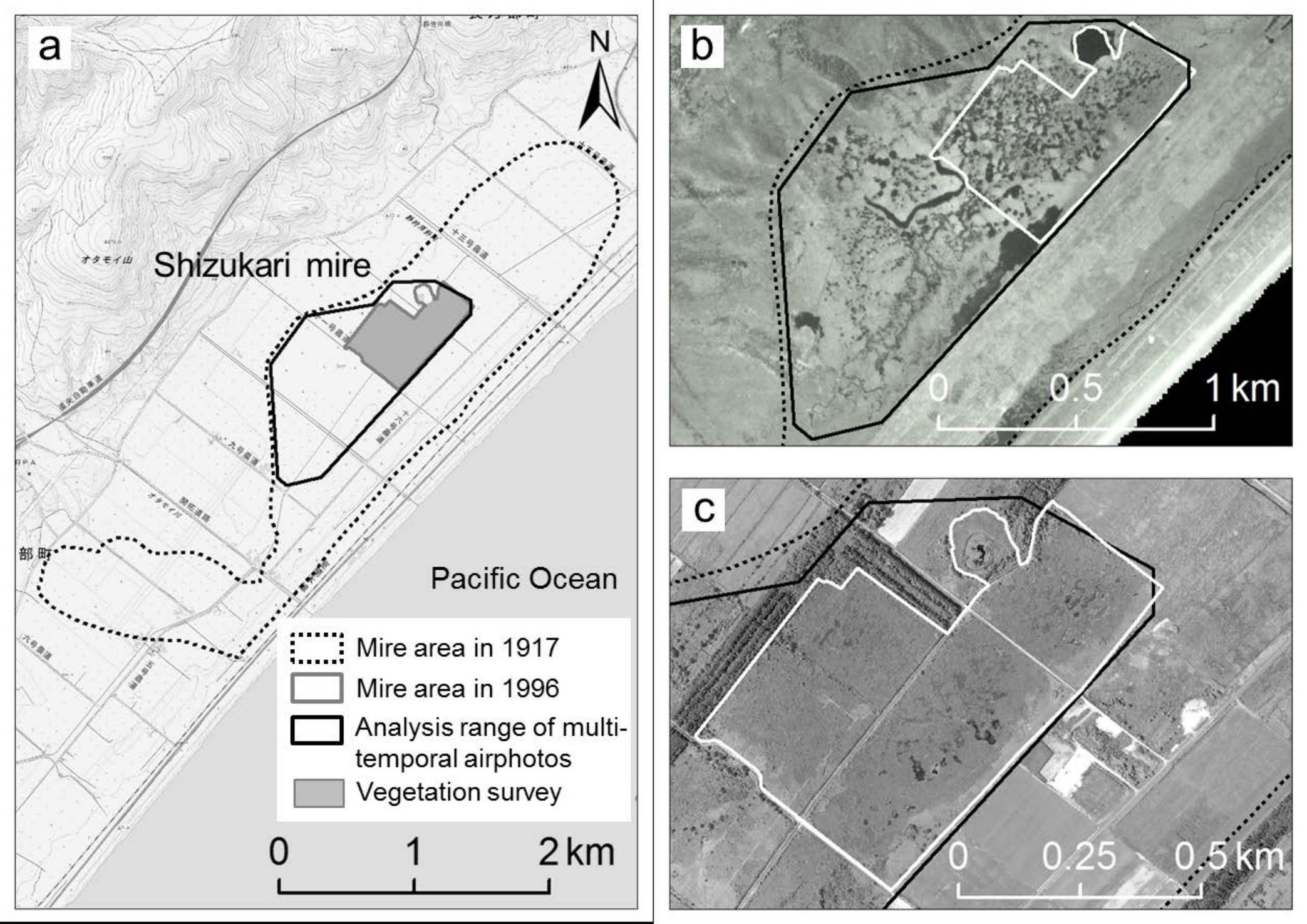




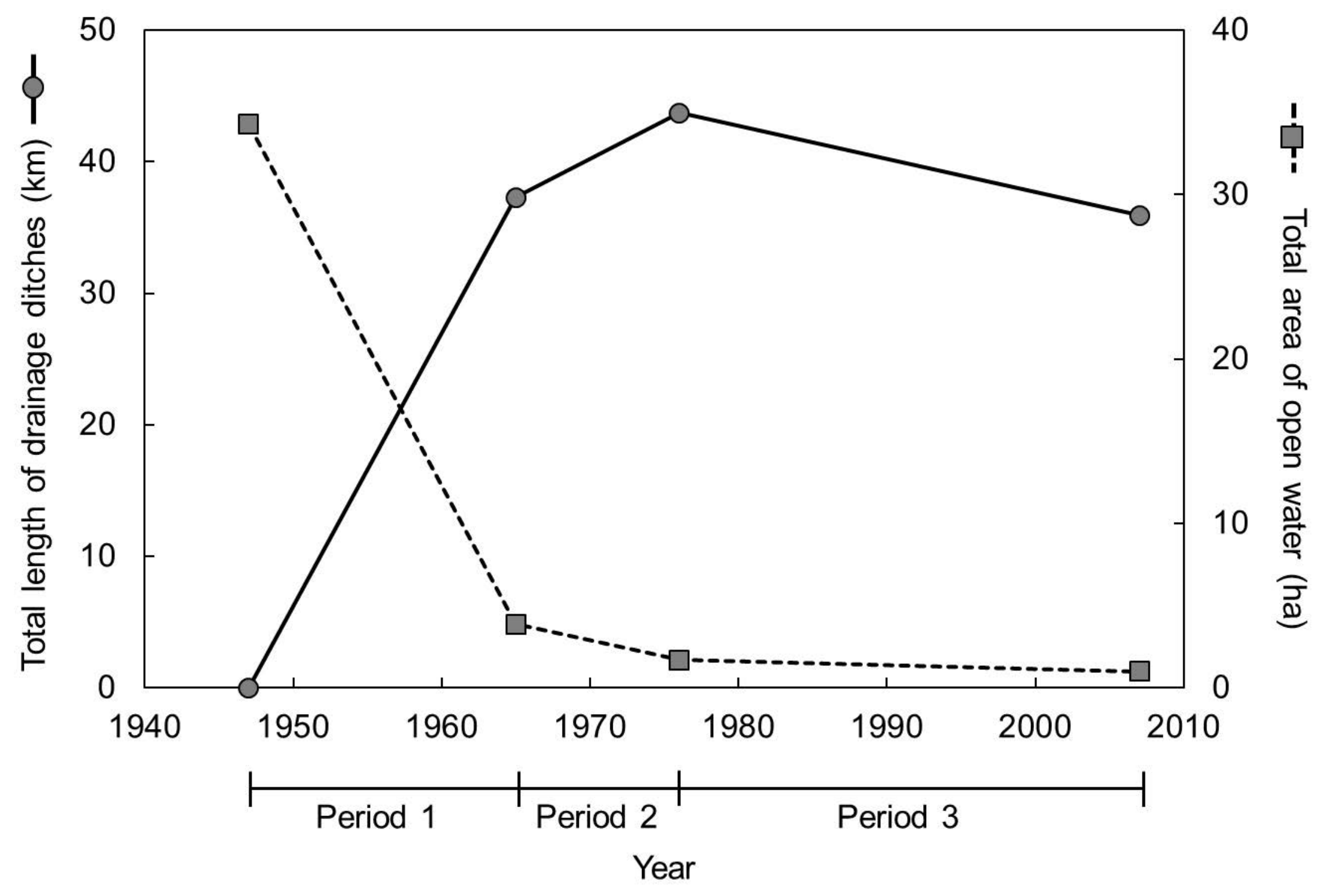




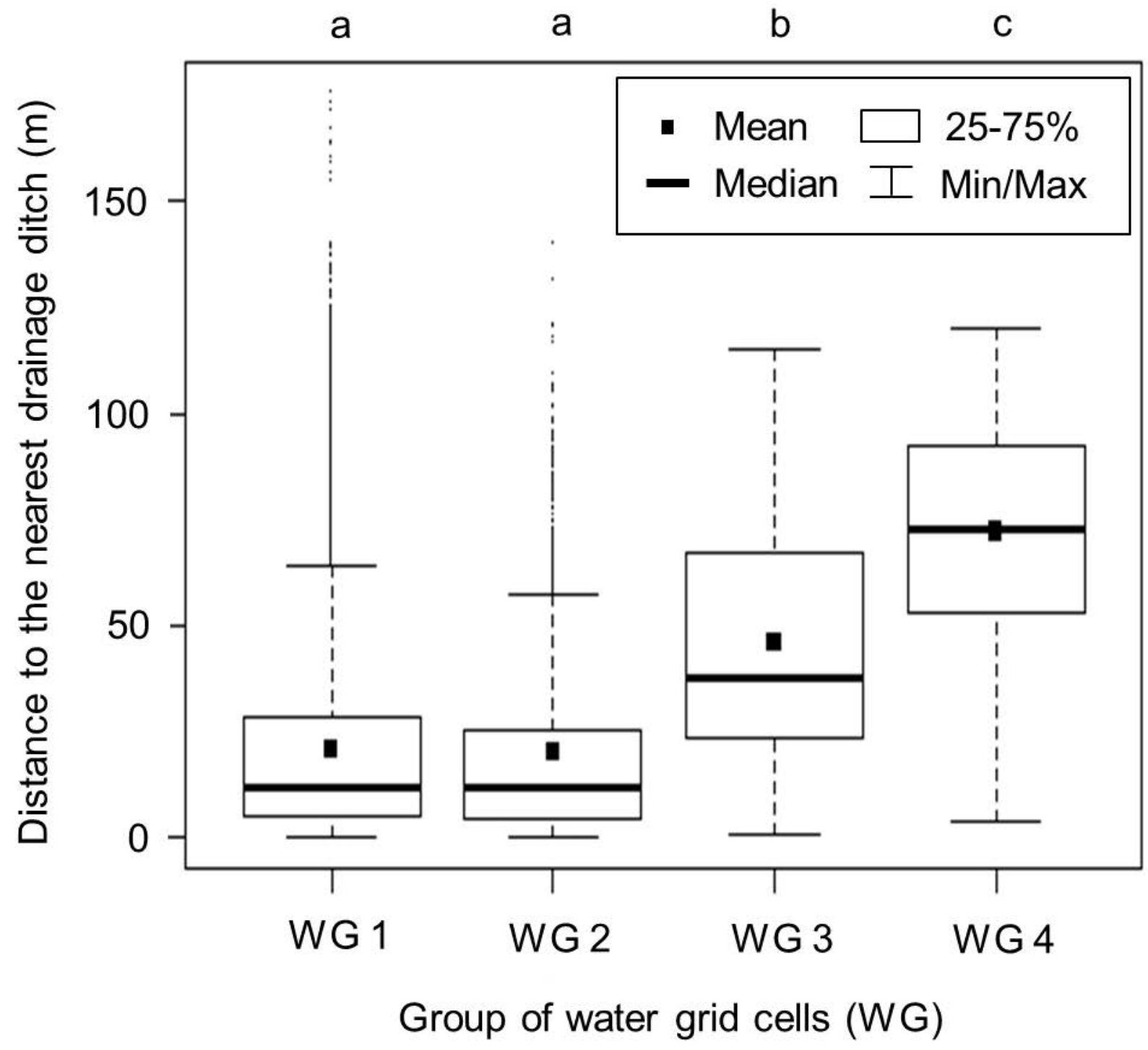


a

$$
N-M
$$

b

$M-R$

C $\quad R-M$

d $\quad M-S$

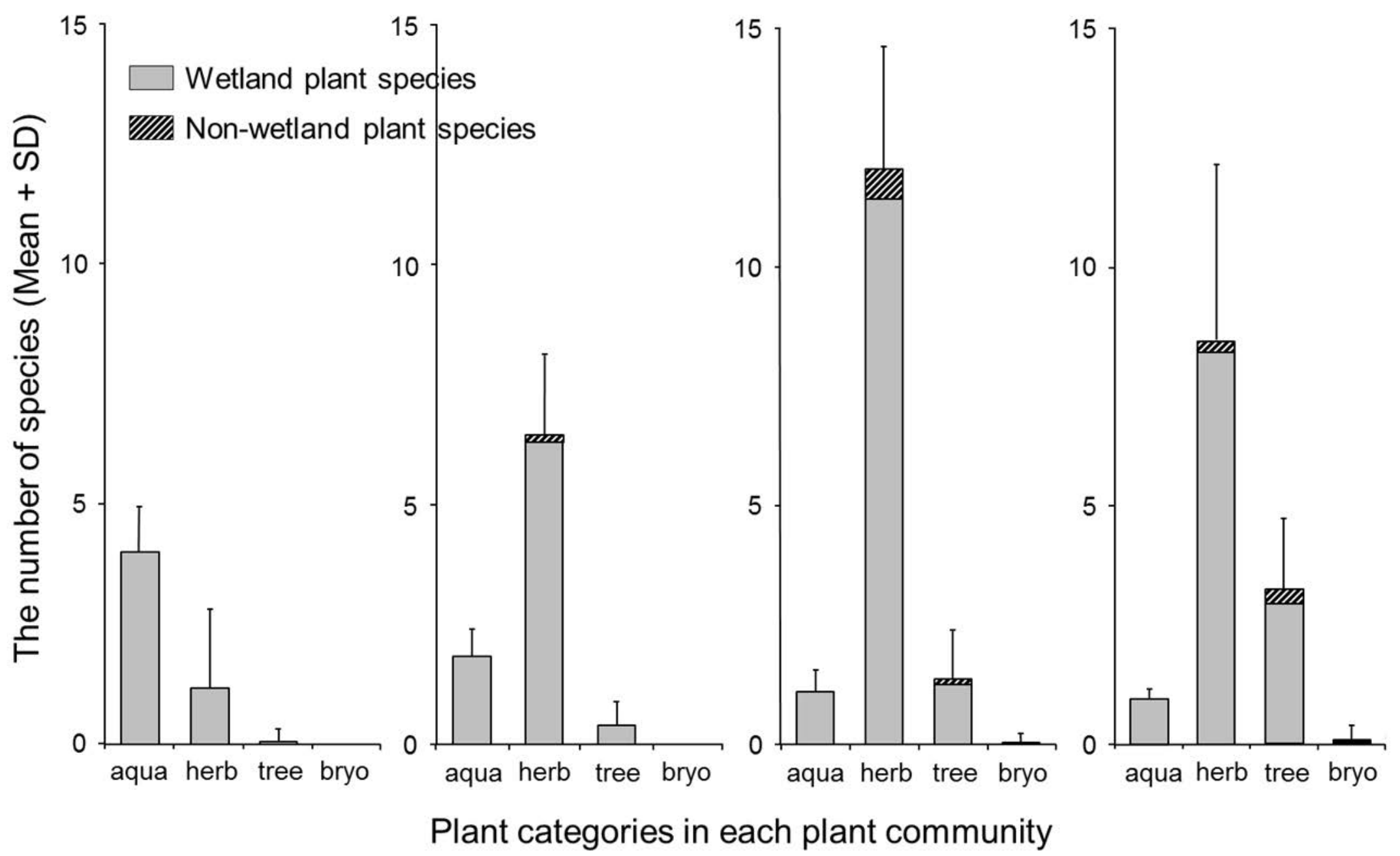




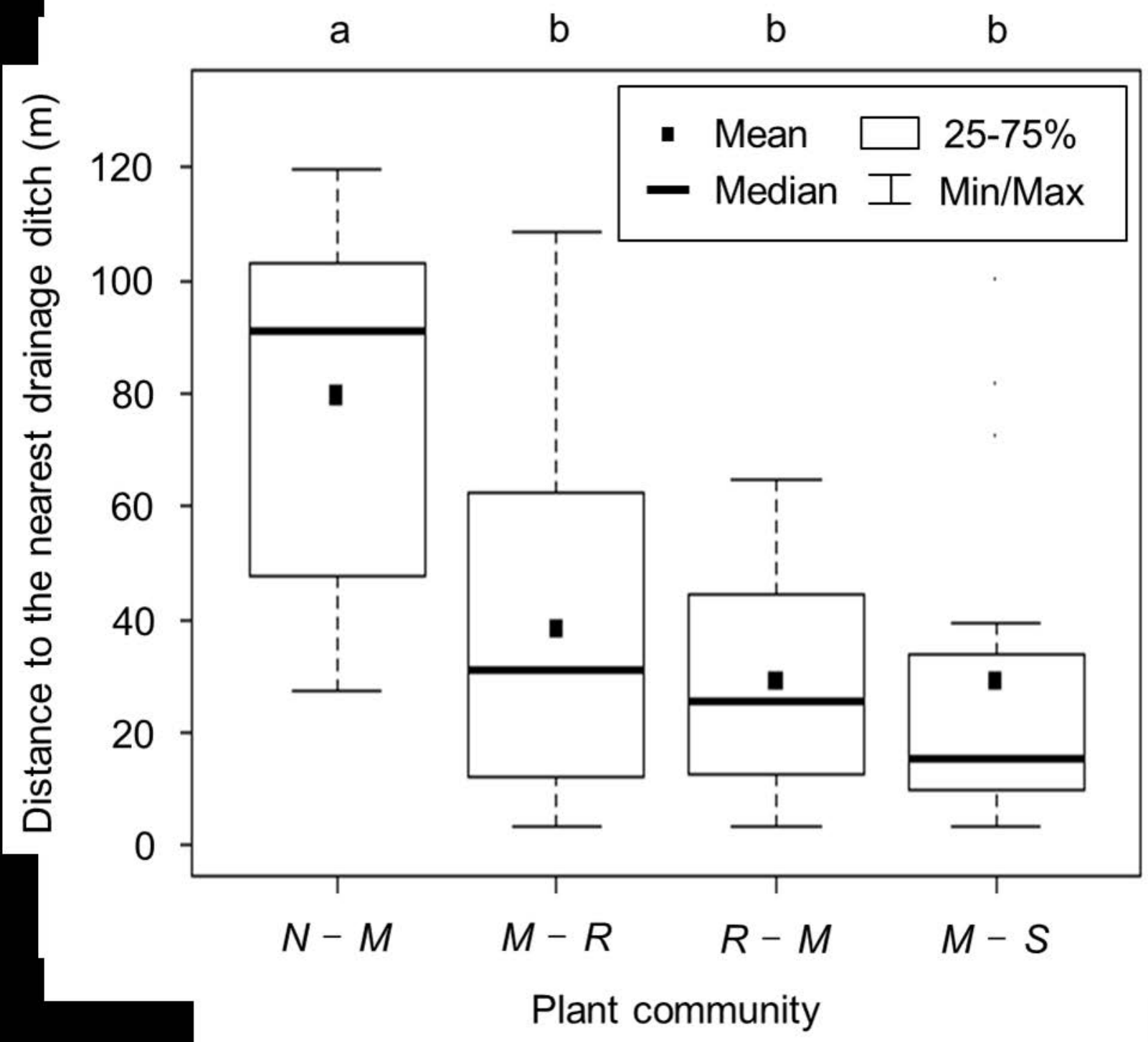




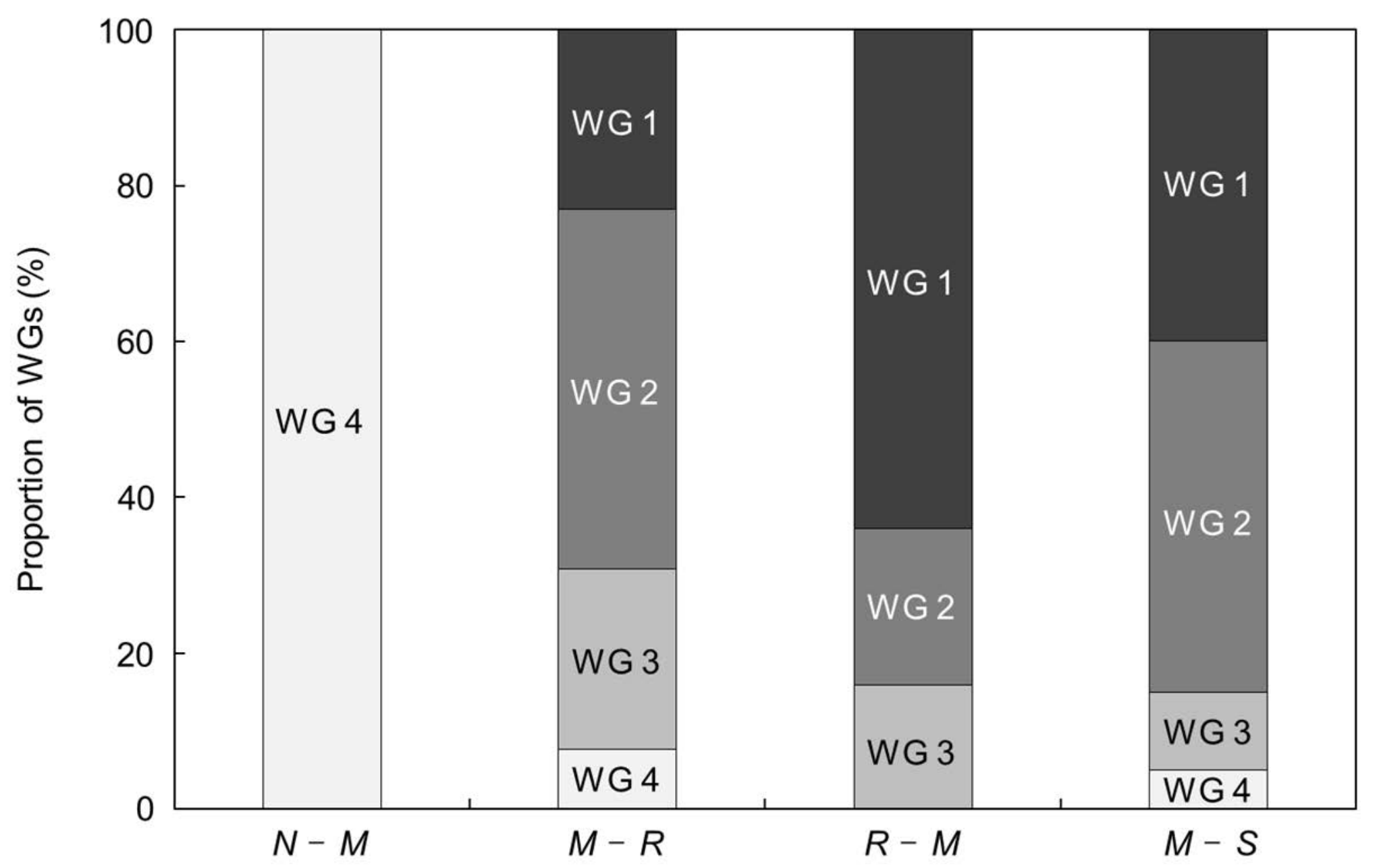

Plant community 